combined to raise the total expenditure, and the total reserves at the end of the year of $£ 158,673$ still fell short of the aim to obtain a sum equal to the amount required for one year's working.

The report gives prominence to the proposal by the Council in July 1964, and the agreement in December 1964 , to purchase the Fulmer Research Institute. The reasons for the bold venture were announced in the February issue of the Bulletin when the purchase was made. Not only will the staff at the Research Institute benefit from close association with the Institute and Society, but investment by the Institute and Society in sponsored research, regarded solely as a business venture, will be evidence that the Council is of the opinion that the application of physics to industry is a paying proposition. The purchase was made possible by the generous terms of the owners' offer and by a substantial interest-free loan made to the Institute and Society by Imperial Chemical Industries, Ltd. It is intended that surplus revenue from the Fulmer Institute will be used to help to replace the income at present derived from the seven-year covenants signed by a number of industrial firms in favour of the Physics Trust Fund and which will stop in 1967 and 1968. S. WeINTROUB

\title{
SCIENTIFIC RESEARCH IN NEW ZEALAND
}

$\mathrm{T}$ HE National Research Advisory Council, New Zealand, was established by the National Research Advisory Council Act of 1963 to advise the Minister of Science on matters related to scientific research in New Zealand. Its first annual report covers the year ending March 31, $1965 *$.

At its first meeting in April 1964, the National Research Advisory Council decided to set up 16 working parties to review and report on research and service in various fields. The reports of these working parties cover: (1) agriculture and forestry, the dairy industry, field crops, forestry, horticulture, meat and wool; (2) secondary and tertiary industry, building and construction, manufacturing and engineering, and transport; (3) earth and related sciences, the atmospheric sciences, mineral resources, oceanography, limnology and fisheries and solid earth sciences; (4) basic sciences, training and services, atomic energy (scientific services for Government departments and agencies are appended); (5) manpower, education and training (this report was deliberately delayed until the working party was able to consider the recommendations of the other working parties and to obtain additional information on manpower).

Meanwhile, the Council is satisfied that the implementa. tion of its present recommendations is foasible and would not be jeopardized by a shortage of trained manpower.

For the year ended March 31, 1965, the estimated expenditure on scientific research and services was about $£ 7.5$ million and in addition $£ 827,000$ was scheduled for expenditure on now laboratories for Government departments and research associations; the total expenditure represented about 0.48 per cent of the gross national product. Of the $£ 7.5$ millions, $£ 6 \cdot 1$ millions was provided on the votes of eleven Government departments and, of this, $£ 661,000$ went in grants to other research organizations. These figures probably underestimate the total expenditure on science since no allowance is made for expansion by the Post Office, railways, the Broadcasting Corporation, or for the salaries of university staff, accom-

* New Zealand. Report of the National Research Advisory Council for the year ended 31 March, 1965. Pp. 51. (H. 41.) (Wellington: Government Printer, 1965 . modation or services provided from university funds and used in part for research.

Between 1954-55 and 1964-65 expenditure on science in Now Zealand increased from $£ 2.73$ millions at about 10 per cent annually, and the scientific staff in Government departments increased in the same period from 568 to about 800 . The Council suggests that investment in research for an industry should depend on such criteria as the annual value of production; the national importance of the industry; the significance and number of problems affecting the industry; the chances of a solution being found to selected problems, taking into account the amount of existing scientific information required; the calibre of the staff available and the availability of suitable facilities; the application of results, bearing in mind the problem of implementation because of difficulties of liaison and information services and the time-lag in the application of research results.

The Council recommends that every effort should be made to increase the research effort directed towards New Zealand's agricultural and pastoral products, particularly those of the meat, wool and dairy industries, and that over the next five years research expenditure in this area. should be increased cumulatively by $£ 320,000$ a year. Forestry research also requires expansion, and a cumulative increase in expenditure of $£ 40,000$ per year is recommended. Very high priority to research into problems of the transport industry is also recommended, including an expenditure starting at $£ 10,000$ a year and rising to $£ 50,000$ a year in five years, while a Transport Research Advisory Committee should be set up to advise the Commissioner of Transport on the operations of the proposed Research Unit. An additional $£ 26,000$ is recommended for the existing building research units, and increased support for operational research in the Department of Scientific and Industrial Research and other organizations is highly desirable. An increase in the next year of about $£ 3,000$, rising to $£ 18,000$ in about

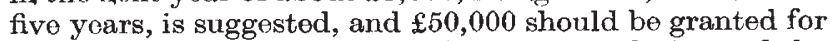
implementing the second year's recommendations of the report of the Mineral Resources Committee.

\section{COMPARATIVE STUDY OF HOUSING IN BRITAIN, FRANCE AND WESTERN GERMANY}

$\mathrm{B}^{\mathrm{r}}$ ROADSHEET No. 490, issued by Political and Economic Planning and prepared by E. G. Howes, deals with housing in Britain, France and Western Germany*.

In Britain, building research is financed to the extent of about $\$ 900,000$ per annum at the Building Research

* Planning, 31, No. 490 (August 1965): Housing in Britain, France, and Western Germany. By Eric G. Howes. Pp. 215-270. (London: Political and Economic Planning, 1965.) 7s. $6 d$.
Station, and some $£ 100,000$ is spent by the Civil Engineering Research Council; the Minister of Works and Public Building has placed research contracts to the amount of $£ 50,000$ with universities. Most building research is carried out privately, but whether this is adequate and whether the information gained is accessible is regarded as very doubtful. In Germany the Federal Government and the Regents devote considerable funds to research and the nationalization of techniques and procedure, and also 
support exhibitions, publications, films and other means of disseminating information (no figures for expenditure, however, are given in the Broadsheet).

For the rest, the Broadsheet concludes that British standards in housing are still high in comparison with those of France, but are being overtaken by those of West Germany. In numbers of dwellings built in recent years (until 1964) Britain has been lagging. Her present need is to step up new building schedules, particularly of dwellings to let, and to demolish and replace slums. Housing policy in Britain has been confused by indecision as to whether the provision of houses should be regarded as a social service, or as a commercial operation. The existence of subsidized and also non-profit housing has almost completely stopped the investment of private capital in dwellings for letting.

While it is proper that local authorities should have the major responsibilities for housing families of all incomelevels, it may be argued that subsidies should be reserved for those families that, because of age, lack of earning capacity, or other handicaps, are unable to afford economic rents. In both France and Western Germany the policy is to grant housing allowances to such families and the consequences of adopting such a system in Britain should be explored. In Britain the National Assistance Board pays out rent allowances to 1.5 million families that are eligible for assistance, but the policy elsewhere is to make a clear distinction between housing allowances and public assistance. It is desirable also to diversify the means by which houses for letting at economic rents should be provided : the recently created Housing Corporation should be given every support in its encouragement of cost-rent and ownership societies. There seems to be no point in deterring the private sector from competing in this field.

Adoption of long-term planning policies would enable those engaged in producing dwellings to plan ahead and to concentrate on their work without fear of too frequent change. It is impossible to ignore the success of the German housing problem and the extent to which this is attributable to long-term policies. The efforts of Western Germany to influence the supply and price of building land have not always been fully rewarded, but have achieved some part of their object. Ways and means whereby the British Government could exert an adequate influence have received intensive study, and action is now urgently required. If tax concessions are to be given to some form of saving, like those of Trustee Savings Banks, it is arguable that equivalent concessions should be awarded to Building Societies, the efforts of which are directed exclusively to providing finance for housing. The psychological and material effects of such measures have been clearly demonstrated in Western Germany by the successful revival of the saving habit. Encouragement should be given to the house-building part of the construction industry to rationalize its organization, cut out restrictive practices, intensify training and make the best possible use of the skills and knowledge of its manage. ment and work people. The possibility of further curtailment of the apprenticeship period with more intensive training and training on actual work is worth considering. Consideration might also be given to whether it is politic to allow public, commercial and industrial building to outstrip the building of dwellings. Experience in Germany and France suggests that self-building societies, which in a small way have done useful work, could be more vigorously encouraged in Britain.

The Broadsheet considers that the trained personnel of the British building industry are probably of as high a calibre as, if not higher than, their counterpart in other countries, and to perform the task that confronts them they need only the leadership, guidance and encouragement that vigorous Government backing can provide.

\section{INSPECTION OF ALKALI, ETC., WORKS}

$\mathrm{T}$ HE one hundred and first annual report on alkali, etc., works in England and Wales, prepared by the Chief Inspector*, covers the year 1964. It stresses the co-operation of industry with the Inspectorate without which, individually by works, and collectively through research associations, and the like, the task of the Inspectorate would be much more onerous. Certainly without this co-operation the Inspectorate would have to be multiplied several times in size and a department would bo needed for specialized techniques of waste gas sampling and analysis, as well as for developing control measures for air pollution. The number of works registered under the Act at the end of the year was 1,995, involving the operation of 3,208 processes, and 11,966 visits and inspections were paid during the year, compared with 10,850 in 1963 , including 123 special visits by the Chief and Deputy Chief Inspectors. Of this total, 231 were to, or in connexion with, works not registered under the Act, 46 were concerned with control of radioactive emissions and 37 were to, or in connexion with, colliery spoilbanks. During the inspections 4,563 quantitative analyses were made of gases ovolved from processes in operation, compared with 3,433 in 1963 , while 746 special samples, compared with 615 in 1963, wero taken and submitted to the Government Chemist.

The report also emphasizes the effect of the changing face of industry on the task and responsibilities of the inspectorate; a searching and realistic appraisal of the responsibilities and day-to-day activities of the inspectorate has been made. A historical and technical review of the decline and fall of the traditional sulphuric acid

* Ministry of Housing and Local Government-Scottish Development Department. One Hundred and First Annual Report on Alkali, etc., Works
by the Chief Inspectors, 1964. Pp. iv + 76. (London: H.M.S.O., 1965.) 5s. $6 d$. net. lead chamber process and one of the early days of the copper industry are included.

In the belief that most new contact sulphuric acid plants will burn sulphur of high quality as the raw material, tables have been prepared giving the stack heights for final discharge of waste gases from units or clusters of units making daily $200-2,000$ tons of monohydrate. If different raw materials are used it will be a simple matter for inspectors and industry to calculate appropriate chimney heights using the information given and to apply it to the particular permitted loss of sulphur burned. Reference is again made to mist emission from certain contact sulphuric acid plants, and while our knowledge of the reasons for this is still obscure the problem receives the close attention of the Inspectorate (some progross appears to have been made).

The Chief Inspector, under "Alkali, etc., Works and Regulations (Scotland) Acts, 1906 and 1951", records that, at December $31,1964,263$ works were registered under the 1906 Act, and 361 processes were inspected within these works. 622 visits were paid by the Inspectorate on work under the Act or in the interest of preventing air pollution, of which 420 were to premises registered under the Act of 1906.

Further experimental testing of emissions of dust from registered premises was carried out on behalf of the Inspectorate by the two-man team provided on contract by the Department of Scientific and Industrial Research. Thirteen works were covered in 41 visits, and 87 tests were made mostly at the electricity power stations. In general, inspections showed that the provisions of the Act were observed in good spirit as well as with attention to the tests. 